\title{
WEIGHTS OF CYCLIC AND PREGNANCY CORPORA LUTEA OF DAIRY COWS
}

\author{
M. J. EDWARDS* \\ University of Liverpool, Veterinary Field Station, Neston, Cheshire \\ (Received 15th November 1961)
}

\begin{abstract}
Summary. The weights of 114 cyclic and 245 pregnancy corpora lutea have been compared and some sources of their variations assessed. It was found that the pregnancy corpus luteum (corpus luteum verum) was significantly heavier than the cyclic corpus luteum. Variations were found in the weights of corpora lutea vera due to the stage of gestation and to the season in which conception occurred. The corpus luteum verum increased in size until 2 to 3 months of gestation and then regressed until 4 to 6 months of gestation, remaining about this size until term. A similar pattern of growth and regression was followed at various weight levels according to the season in which conception occurred. Although no seasonal variation in weight was noted in cyclic corpora lutea, corpora lutea vera attained the greatest weights following conceptions during summer and the smallest weights were found following conceptions in winter.
\end{abstract}

\section{INTRODUCTION}

It is generally recognized that the corpus luteum of dairy cows in the dioestrous period attains maximum size after about 8 days following ovulation and remains about this size until the 18th day after which it rapidly regresses. A wide variation in the size of fully developed cyclic corpora lutea and of corpora lutea of pregnancy has been reported by a number of authors (Hammond, 1927; Wright, 1950; Foley \& Greenstein, 1958). Whether the corpus luteum of pregnancy (corpus luteum verum) differs in size from the fully developed corpus luteum of the dioestrous period (cyclic corpus luteum) and whether the corpus luteum verum remains the same size throughout gestation are the subjects of some controversy. Wright (1950) found the weights of corpora lutea vera to range from 3.9 to $7.5 \mathrm{~g}$. He believed that any difference in weight between cyclic corpora lutea and corpora lutea vera was too slight to be of significance and that the corpus luteum verum persisted at its maximum size throughout gestation. Hammond (1927) found that the corpus luteum verum was slightly larger than the cyclic corpus luteum and believed that it remained constant in size throughout gestation. However, Bretschneider, de Wit \& van der Kaay (cited by Dawson, 1959) and Kupfer (cited by Hammond, 1927) found that corpora lutea vera increased in size early in pregnancy and became

* Present address: University of Sydney, Rural Veterinary Centre, Camden, N.S.W., Australia.

D 93 
smaller in late pregnancy. Stormshak \& Erb (1961) reported similar variations at a non-significant level and noted a degree of breed variation, corpora lutea vera from dairy cows being heavier than those from beef cows.

This paper discusses the variations found in the sizes and weights of corpora lutea vera and of cyclic corpora lutea from a group of dairy cows.

\section{MATERIAL AND METHODS}

Apparently normal reproductive tracts were obtained from dairy cows at an abattoir in Birkenhead, England, between September 1959 and February 1961. During this period, the breeds of 502 of the cows examined were recorded as Friesian $52.6 \%$, Ayrshire $27.3 \%$, Shorthorn 9.2\%, Jersey $5.2 \%$, Guernsey $3.6 \%$, Welsh Black $0.8 \%$, crossbreeds $1.3 \%$.

The corpus luteum was dissected from the ovary, measured across the widest diameter, sectioned and weighed. A cyclic corpus luteum was considered to be at the stage of maximum development when its widest diameter exceeded $2 \cdot 0 \mathrm{~cm}$, its colour was yellow to orange-yellow, and the luteinized

TABLE 1

COMPARISON OF DIAMETERS AND WEIGHTS OF GYCLIC AND PREGNANGY GORPORA LUTEA

\begin{tabular}{l|c|c|c|c}
\hline & $\mathrm{n}$ & $\begin{array}{c}\text { Mean } \\
\text { diameter } \\
(\mathrm{cm})\end{array}$ & $\begin{array}{c}\text { Mean } \\
\text { weight } \\
(\mathrm{g})\end{array}$ & $\begin{array}{c}\text { s.D. } \\
(\mathrm{g})\end{array}$ \\
\hline $\begin{array}{ll}\text { Cyclic corpora lutea } \\
\text { Corpora lutea vera }\end{array}$ & 114 & 2.30 & $5 \cdot 71$ & 0.998 \\
\hline & 245 & $2 \cdot 46$ & 6.52 & $1.287 *$ \\
\hline
\end{tabular}

pleats had formed an homogeneous compact mass supported by the connective tissue reticulum. Observations on dioestrous corpora lutea from heifers or those enclosing a central fluid filled cavity were not included. In pregnant specimens, the foetal body length was measured as a straight line between the most anterior point on the frontal bones, and the rump at the sciatic tuberosity; the stage of pregnancy, and the season in which conception occurred, were gauged from this measurement using an average of the figures of crown-rump length in known stages of gestation published by Hammond (1927), Wright (1950), Winters, Green \& Comstock (1942), and Arthur (1957).

\section{RESULTS}

A comparison of the mean diameters and weights of mature dioestrous corpora lutea and of corpora lutea vera is presented in Table 1 and indicates that the latter body is significantly heavier than the dioestrous specimen.

The mean weights of the corpora lutea vera arranged in groups representing stages of gestation as determined by foetal body length form Table 2. The corpus luteum verum appears to continue to enlarge past its mature dioestrous 
size to a maximum at about 2 to 3 months of gestation, and then to regress until about 4 to 6 months of gestation, remaining about this size until term.

Eleven dioestrous corpora lutea observed during winter (December to February) had a mean weight of $5.74 \mathrm{~g}$; during spring (March to May) the mean weight of fifty-two specimens was $5.69 \mathrm{~g}$; during summer (June to August) the mean of twenty-four observations was $5.73 \mathrm{~g}$; during autumn

TABle 2

VARIATIONS IN THE WEIGHTS OF CORPORA LUTEA VERA ACCORDING TO THE STAGE OF GESTATION

\begin{tabular}{l|c|c|c}
\hline \multicolumn{1}{c|}{ Foetal body length } & $\mathrm{n}$ & Mean weight $(\mathrm{g})$ & S.D. $(\mathrm{g})$ \\
\hline 1.2 to $6.5 \mathrm{~cm}$ & 32 & 6.57 & 0.970 \\
$\begin{array}{l}(1 \text { to } 2 \text { months gestation) } \\
6.6 \text { to } 16.4 \mathrm{~cm}\end{array}$ & 52 & 7.21 & 1.369 \\
$\begin{array}{l}(2 \text { to } 3 \text { months gestation) } \\
16.5 \text { to } 28.5 \mathrm{~cm}\end{array}$ & 56 & 6.55 & 1.319 \\
$\begin{array}{l}(3 \text { to } 4 \text { months gestation) } \\
28.6 \text { to } 51.0 \mathrm{~cm}\end{array}$ & 65 & 6.14 & 1.124 \\
$\begin{array}{l}(4 \text { to } 6 \text { months gestation) } \\
51.1 \text { to } 98.0 \mathrm{~cm}\end{array}$ & 40 & 6.17 & 1.158 \\
(6 to 9 months gestation) & & & \\
\hline
\end{tabular}

$F=6.49$ with 4 and 240 d.f., $P<0.001$.

(September to November) the mean of twenty-four observations was $5 \cdot 79 \mathrm{~g}$. The effect of the season in which conception occurred on the mean weights of corpora lutea vera is illustrated in Table 3 ; the variations in weights are highly significant.

In Table 4 the influences both of season of conception, and of stage of gestation, on the mean weights of corpora lutea vera are analysed, and show

TABLE 3

VARIATIONS IN THE WEIGHTS OF CORPORA LUTEA VERA ACGORDING TO THE SEASON IN WHICH CONGEPTION OCGURRED

\begin{tabular}{l|c|c|c}
\hline \multicolumn{1}{c|}{ Season of conception } & $\mathrm{n}$ & Mean weight $(g)$ & s.D. $(g)$ \\
\hline Spring (March to May) & 78 & $6 \cdot 69$ & $1 \cdot 120$ \\
Summer (June to August) & 70 & $6 \cdot 88$ & $1 \cdot 411$ \\
Autumn (September to November) & 34 & $6 \cdot 14$ & $1 \cdot 232$ \\
Winter (December to February) & 63 & $6 \cdot 12$ & $1 \cdot 174$ \\
\hline
\end{tabular}

$F=5 \cdot 62$ with 3 and 241 d.f., $P$ approx. $0 \cdot 001$.

that irrespective of the season in which conception occurred, the mean weights show an increase to 2 to 3 months of gestation, followed by regression to 4 to 6 months of gestation as in Table 2. The levels at the various stages of gestation are in general highest in those specimens following summer conceptions, and lowest in those following winter conceptions. The values for pregnancy corpora lutea following spring conceptions show little variation until 6 to 9 months of gestation. The differences observed in mean weights due to the season of 


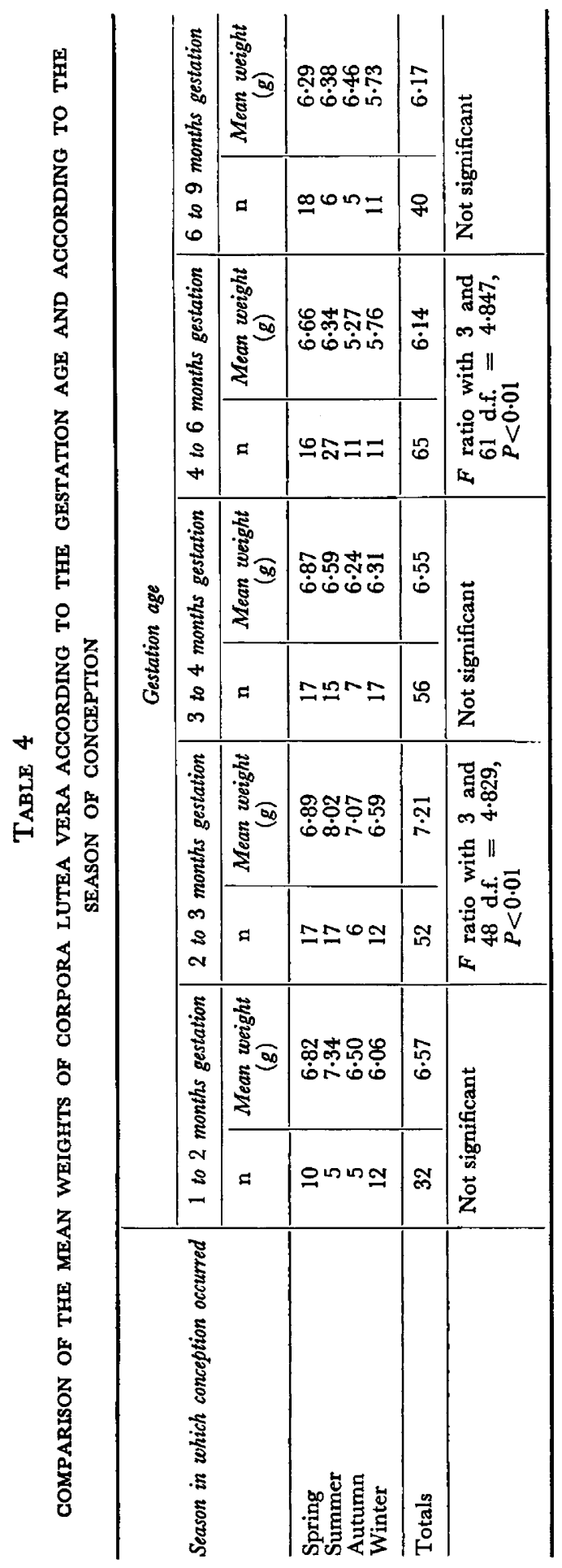


conception at 2 to 3 months and 4 to 6 months of gestation are significant at the $1 \%$ level of probability.

The mean weight of fifteen dioestrous and of thirty pregnancy corpora lutea known to be from Friesian cows were $5 \cdot 75 \mathrm{~g}$ and $6 \cdot 10 \mathrm{~g}$, respectively. These do not differ significantly from the means of all breeds.

\section{DISCUSSION}

A wide range was evident in the weights of both cyclic and pregnancy corpora lutea; the former varied between 4.0 and $9.2 \mathrm{~g}$ and the latter between 3.8 and $10 \cdot 1 \mathrm{~g}$.

It is possible that a number of factors other than those discussed in this paper might influence the size of the corpus luteum. The specimens used in this study were selected to exclude material from heifers or from beef cows, the corpora lutea of which were found in general to be smaller than those from dairy cows. There was no evidence of difference between breeds of dairy cows in the weight of cyclic corpora lutea or in the weight of corpora lutea vera.

An initial increase which was followed by a regression in the weight of corpora lutea vera has been recorded by Kupfer (cited by Hammond, 1927), Bretschneider et al. (cited by Dawson, 1959), and Stormshak \& Erb (1961), but the extreme atrophy in late gestation reported by Bretschneider et al. was not observed in the present study; the mean weight of eleven corpora lutea vera from specimens between the 8- to 9-months stage of gestation was $5 \cdot 82 \mathrm{~g}$. It appears that the stimulus (or stimuli) maintaining the corpus luteum verum after conception might also exert an influence of varying degrees of intensity throughout gestation, producing an enlargement in size in early pregnancy and a diminution in size later. The intensity of the stimulus appears to be greatest if conception occurs during summer, and least if conception occurs during winter. However, the mean weights of cyclic corpora lutea show no evidence of variation due to seasonal influences.

\section{ACKNOWLEDGMENTS}

Thanks are due to the Fat Stock Marketing Corporation who supplied the specimens of genitalia from the Tranmere Abattoir, Birkenhead.

I am indebted to Professor J. G. Wright for his helpful criticism during this study which was performed under his direction at the Veterinary Field Station of Liverpool University at Neston, Cheshire, and also to Professor H. O. Lancaster, Department of Mathematical Statistics, University of Sydney, for his help in the tests of significance.

\section{REFERENCES}

ARThUR, G. H. (1957) Some notes on the quantities of foetal fluids in ruminants with special reference to 'hydrops amnii'. 1. The normal foetal fluids. Brit. vet. F. 113, 17.

Dawson, F. L. M. (1959) Enucleation of the bovine corpus luteum. Vet. Rec. 71, 918.

Foley, R. C. \& GREenstein, J. S. (1958) Early embryology of the cow. 1. Gastrula and primitive streak stages. F. Dairy Sci. 41, 409.

Hammond, J. (1927). The physiology of reproduction in the cow. Cambridge University Press, London. 
Stormshak, F. \& ERB, R. E. (1961) Progestins in bovine corpora lutea, ovaries, and adrenals during pregnancy. F. Dairy Sci. 44, 310.

Winters, L. M., Green, W. W. \& Comstock, R. E. (1942) Prenatal development of the bovine. Tech. Bull. Mo. agr. exp. Sta. No. 151.

Wright, J. G. (1950) Veterinary obstetrics. Ed. F. Benesch \& J. G. Wright, Baillière, Tindall \& Cox, London. 